Document downloaded from:

http://hdl.handle.net/10251/143322

This paper must be cited as:

Domenech-Carbo, A.; Domenech Carbo, MT.; Valle-Algarra, FM.; Gimeno-Adelantado, J.; Osete Cortina, L.; Bosch-Reig, F. (07-2). On-line database of voltammetric data of immobilized particles for identifying pigments and minerals in archaeometry, conservation and restoration (ELCHER database). Analytica Chimica Acta. 927:1-12.

https://doi.org/10.1016/j.aca.2016.04.052

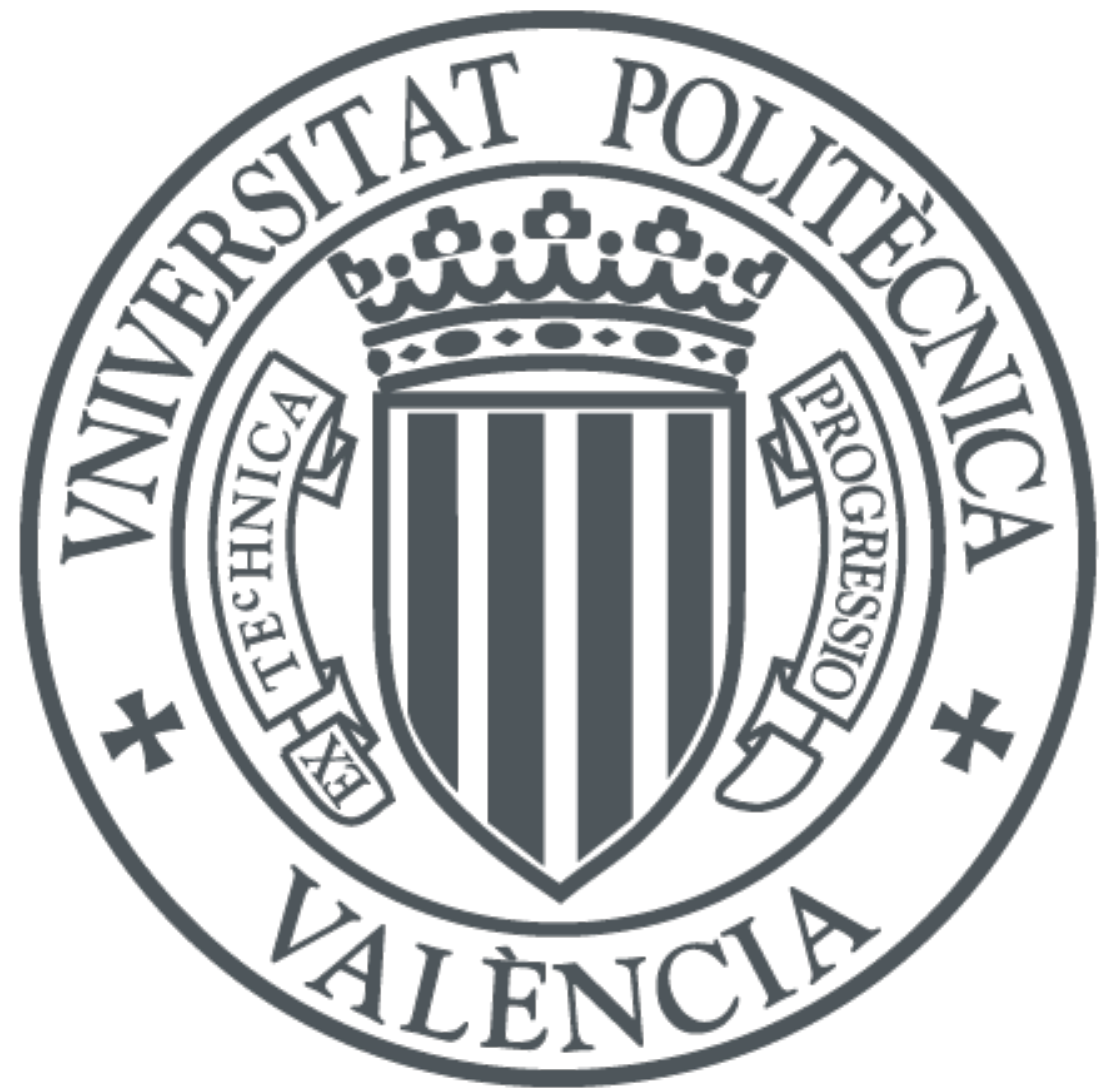

The final publication is available at

https://doi.org/10.1016/j.aca.2016.04.052

Copyright Elsevier

Additional Information 


\title{
On-line voltammetry of immobilized particles database of pigments and minerals for archaeometry, conservation and restoration (ELCHER database)
}

\author{
Antonio Doménech-Carbó*a ${ }^{\mathrm{a}}$, María Teresa Doménech-Carbó* ${ }^{\mathrm{b}}$, Francisco Manuel \\ Valle-Algarra ${ }^{\mathrm{a}}$, José Vicente Gimeno-Adelantado ${ }^{\mathrm{a}}$, Laura Osete-Cortina ${ }^{\mathrm{b}}$, Francisco \\ Bosch-Reig ${ }^{\mathrm{a}}$
}

${ }^{a}$ Departament de Química Analítica. Universitat de València. Dr. Moliner, 50, 46100 Burjassot (València) Spain.

${ }^{\mathrm{b}}$ Institut de Restauració del Patrimoni, Universitat Politècnica de València, Camí de Vera 14, 46022, València.

* Corresponding authors. E-mail: antonio.domenech@uv.es and tdomenec@crbc.upv.es.

Keywords: Voltammetry; Pigments; Database; Archaeometry; Conservation and restoration.

\begin{abstract}
A web-based database of voltammograms is presented for characterizing artists' pigments and corrosion products of ceramic, stone and metal objects by means of the voltammetry of immobilized particles methodology. Description of the website and the database is provided. Voltammograms are, in most cases, accompanied by scanning electron microphotographs, $\mathrm{x}$-ray spectra, infrared spectra acquired in attenuated total reflectance Fourier transform infrared spectroscopy mode (ATR-FTIR) and diffuse reflectance spectra in the UV-Vis-region. For illustrating the usefulness of the database two case study involving identification of pigments and a case study describing deterioration of an archaeological metallic object are presented.
\end{abstract}

Keywords: Voltammetry of immobilized particles; Database; Pigments; Corrosion products. 


\section{Introduction}

The elucidation of the composition of artist's materials and their alteration products is an essential analytical target in archaeometry and conservation of cultural heritage. These analytical studies are particularly important in regard to pigments. Relevant information for authentication, dating and provenance studies, identification of repainting and testing deterioration degree can be obtained from the study of pigments present in paintings, polychromed sculptures and decorative elements [1,2]. Most coloring materials historically used by artists are natural products such as minerals, often chemically treated, and organic extracts and exudates from plants (more rarely from animals) rather than chemically pure substances. Accordingly, the interpretation of the analytical data provided by available instrumental techniques requires the disposal of a wide reservoir of case-sensitive standards. This has motivated the recent appearance of libraries containing UV-visible spectra, FTIR/Raman spectra and X-ray diffraction data for minerals and artist's pigments [4-17].

On the other hand, available techniques for pigment analysis have been expended by the development of the voltammetry of immobilized particles (VIMP), a methodology developed by Scholz et al. prompting the electrochemical characterization of solid materials, early applied to minerals [18-21] and pigments [22]. As recently reviewed, the VIMP can be applied to the identification, mineralogical and oxidation state speciation and quantification of selected analytes in a variety of materials [23-25] and applied to the study of works of art [26-28] using amounts of sample in the microgramnanogram range.

The special requirements of the analytical procedures when they are applied to works of art and archaeological artifacts makes VIMP particularly useful because of its inherently high sensitivity, requirement of minimal amounts of sample, no need of sample pretreatment and partial sample recuperation and use for multiple analysis. Since its first application for identifying inorganic pigments [29], the VIMP methodology has been increasingly used in the analysis of pigments in works of art [30-38], their alteration products [36,38], as well as metal corrosion products [40-44]. The scope of this technique in the archaeometric field has been enhanced by the use of 'graphite pencil' sampling [45-48], local [49,50] and layer-by-layer analysis [51]. The analytical 
capabilities of VIMP have been expanded to provide relevant information for the authentication [52,53], tracing and dating [54-57] of archaeological metal. Hybrid inorganic-organic pigments of historical relevance such as Maya blue have also been studied by VIMP [58-64].

The purpose of the current report is to present a web-based database "Electrochemistry for Heritage" (ELCHER) covering the VIMP response of artist's pigments and products of alteration of stone, ceramics, metals and pigments and discuss the capabilities and constraints associated to the same, illustrated by selected case studies. The voltammograms database is complemented with scanning electron microphotographs and x-ray spectra, IR absorption spectra obtained by ATR-FTIR and UV-vis diffuse reflectance spectra. A complementary set of data from SECM and AFM coupled to electrochemical measurements is presented. Such data are of interest for applying them in the conservation and restoration field where these analytical techniques have been recently applied for the localization of proteins in paint layers [65] and the identification of pigments and corrosion products at the nanoscopic scale $[37,66]$.

\section{The ELCHER database}

The ELCHER database is available on the internet website: http://www.elcher.info. The website was developed using HTML 4.0, CSS 2.0, PHP 4.0 and JavaScript programming languages. The voltammograms as well as microphotographs, x-ray, IR and reflectance spectra are available online. The whole database has, at this moment, 100 voltammograms, 30 x-ray spectra, 50 ATR-FTIR spectra (spectral range: 600-4000 $\mathrm{cm}^{-1}$ ) and $50 \mathrm{UV}$-vis spectra (spectral range: 200-800 nm) of 70 different materials specifically used by artists from prehistoric times until nowadays.

The home page contains a banner with graphs and photographs of a selection of pigments from the database. The web page is organized in seven areas (Fig. 1a). Tabs in the header allow the user to move from one major content area to another. The first area includes general information on the electrochemistry for heritage (ELCHER) research group (background, organization chart and facilities and equipments). The second area is a summary of the main results obtained by the ELCHER group in the last years $(R+D$ projects, papers and books). The main results of a case study of relevance are shown in 
the fourth area. The fifth area contains the ELCHER database. The sixth to seventh page and the research group. Instrumentation and other details of voltammograms and spectra contained in the database may be obtained by clicking on "About Elcher Database" in the pull-down menu of the database tab in the main page. To start navigating through the database, users must click on the "search" button on the pulldown menu of the database tab after ticking the box "accept terms of use and legal conditions" (see Fig. 1b). Access to the voltammogram and spectra of a specific pigment or mineral is possible by writing the name of the pigment in the keyword box (Figure 2a). Restricted search can be carried out by selecting the option "common name", "material type" or "data type" in the box "search by". Then the page of the material selected appears. This page contains the following: voltammogram, filename, the pigment's common name in English and Spanish languages, supplier or provenance data, chemical composition, acquisition conditions of the voltammogram. If available, $\mathrm{x}$-ray, backscattered electron photograph, IR and UV-vis spectra are shown (Figure 2b). To a magnified view of the desired voltammogram, spectrum or microphotograph, users must click on the "voltammogram" or spectrum box which then opens a pop-up window with the image requested.

\section{Experimental}

\section{Reagents and reference materials}

Data presented here correspond to Kremer pigments (Aichstetten, Germany). Sodium acetate, acetic acid, hydrochloric acid (Panreac), acetone (Sigma) and Paraloid B72 (Rhöm \& Haas) were used as chemical reagents.

\section{Instrumentation}

VIMP experiments were performed at $298 \mathrm{~K}$ in a three-electrode cell under argon atmosphere using a CH I660C device (Cambria Scientific, Llwynhendy, Llanelli UK) and Ivium CompactStat (Ivium Technol. B.V., Eindhoven, The Netherlands) portable equipment. A platinum wire counterelectrode and a saturated calomel reference electrode (SCE) completed the three-electrode arrangement. Aqueous $0.25 \mathrm{M}$ sodium acetate buffer and $0.10 \mathrm{M} \mathrm{HCl}$ were used as electrolytes after being deoxygenated by bubbling Ar during 15 min. Cyclic and square wave voltammograms (CVs and SWVs) 
were obtained using conventional abrasive VIMP protocols [18,19]. Commercial graphite) were used. Importantly, the electrolyte solution was renewed after each electrochemical run to avoid contamination due to metal ions eventually released to the solution phase during electrochemical turnovers. Prior to the series of runs for each material or sample, a conditioning protocol was used to increase repeatability. The electrode surface was polished with alumina, rinsed with water and polished by pressing over paper. In conventional 'scratching' VIMP for reference materials, an amount of 1-2 mg of the solid was previously powdered in an agate mortar and pestle, was extended on the agate mortar forming a spot of finely distributed material. Then the lower end of the graphite electrode was gently rubbed over that spot of sample and finally rinsed with water to remove ill-adhered particles. Sample-modified graphite bars were then dipped into the electrochemical cell so that only the lower end of the electrode was in contact with the electrolyte solution.

For field emission scanning electron microscopy X-ray microanalysis, cross-sections prepared from samples excised of paintings by embedding in polyester resin and polishing with $\mathrm{SiC}$ abrasive disks. Cross-sections were examined under a Zeiss model ULTRA 55 field emission scanning electron microscope, which operated with an Oxford-X Max Xray microanalysis system. Image acquisition was done at the $3 \mathrm{kV}$ accelerating voltage. The chemical composition of pigments was obtained at the $20 \mathrm{kV}$ accelerating voltage and 6-7 $\mathrm{mm}$ was the working distance for the X-ray detector. Samples were carboncoated to eliminate charging effects. A semiquantitative microanalysis was carried out by the ZAF method to correct interelemental effects. The counting time was $100 \mathrm{~s}$ for major and minor elements alike. Element percentages were generated by the ZAF method on the Oxford-Link-Inca EDX software, which was performed to exclude $\mathrm{C}$ to avoid erroneous quantification because the signal detected for this element mainly came from the $\mathrm{C}$ coating applied to samples to suppress charge effects.

\section{Operating database}

\subsection{Voltammetric response}

Generation of a practical database for artists' pigments and corrosion products of art objects involves several analytical problems. The first one is the variability in the possible standard materials, because natural pigments or pigments prepared from natural 
materials have been typically used until recent times. This means that materials with difficulty derives from the texture and composition of the base electrode to be used. Textural and chemical properties of the supporting graphite can influence the voltammetric response of the pigment, at least, in three ways: first, as a result of the different adherence and porosity of the graphite surface, thus yielding a more or less effective 'contact' and a more or less extensive three-phase particle/electrolyte/base electrode junction; second, by producing signals associated to oxygen (hydroquinone, phtalic anhydride and carboxylic, mainly) functionalities in the graphite surface $[67,68]$; third, as a result of the more or less extensive surface area exposed to the electrolyte, determining more or less intense resistive plus capacitive effects on the base line of the voltammogram. Home-made paraffin-impregnated graphite electrodes are preferentially used in VIMP literature, but, as demonstrated by an inter-laboratory trial on iron earth pigments [31], the voltammetric response is sensitive to changes in the carbonaceous material constituting the base electrode. The more or less conductivity, particle adherence, and the appearance of surface oxygen functionalities $[67,68]$ can promote significant changes in the voltammetric response. Additionally, the amount of electrode modifier determines a slight shift in the peak potentials [7]. To face all these problems, it is convenient to adopt common, uniform chemical (electrolyte, base electrode, conditioning protocol) and electrochemical (sweep rate, etc.) conditions and define shape-dependent quantities to define pigment-characteristic parameters (vide infra). According to that and, in order to facilitate standardization, commercial graphite bars of uniform graphite content (HB type, see Experimental section) have been used in this database. The selection of the electrolyte is another important step in the electrochemical identification of pigments. The use of different electrolytes allows the introduction of additional criteria for identification [23-28]. Aqueous 0.25 M sodium acetate buffer and $0.10 \mathrm{M} \mathrm{HCl}$ were used as electrolytes in the ELCHER database.

Figure 3 shows the $\mathrm{CV}$ of a malachite deposit on graphite bar immersed into $0.25 \mathrm{M}$ $\mathrm{HAc} / \mathrm{NaAc}, \mathrm{pH}$ 4.75. This voltammogram is illustrative of the typical response of copper pigments (as well as lead and cadmium pigments) in that electrolyte, yielding a two-electron reduction of the parent copper compound to copper metal in the initial cathodic scan, followed in the subsequent anodic scan, by stripping peaks associated to the oxidative dissolution of the metal deposit electrochemically generated to $\mathrm{Cu}^{2+}$ (aq) 
ions in solution phase. The electrochemical reduction of metal compounds to the corresponding metal can involve a topotactic reduction process via formation of an intermediate hydrated layer, as described by Scholz et al. for lead oxides [69], goethite [70] and silver halides and sulfide [71].

As far as the inorganic pigments consist usually of oxides, hydroxioxides, sulfides, etc., for identification purposes, cathodic signals should be used preferentially. This can be combined with stripping peaks due to the oxidative dissolution of metals, but these latter cannot, in principle, be used to differentiate between different pigments of the same metal. Such cathodic signals are dependent on the composition of the pigment and the electrolyte but are also dependent on the characteristics of the base graphite electrode and the amount of solid abrasively transferred to the electrode surface.

Square wave voltammetry (SWV was systematically used by its inherently high sensitivity and reluctance to capacitive effects [72]. SWV experiments at low frequency carried out with pigments produced, in general, the better results in terms of compromise between sensitivity and peak resolution. This aspect is of particular interest keeping in mind the application of this methodology for the analysis of real pictorial samples, where micro- or nanograins of pigment are accompanied by other components such as bindings, preparative supports, varnishes and/or alteration products. This can be seen in Figure 4 where SWV of malachite transferred abrasively to four different graphite bars immersed into acetate buffer are shown. Anodic stripping peaks are much less sensitive to changes in the base electrode. In several cases, overlapping stripping oxidation signals appear, which are attributable to the superposition of different deposits of the same metal $[73,74]$. It should be noted, however, that co-electrodeposition of metals can produce distorted voltammetric responses as a result of the formation of intermetallic compounds.

From the electrochemical point of view, apart from the above family of pigments, those reducible to metals, a second important group of pigments is constituted by those experiencing reductive or oxidative dissolution processes [23-25]. The most representative example is that of iron oxide-based or earth-type pigments, an extensive family of natural and artificial pigments displaying reductive dissolution processes $[30,31,36]$. The rate of such processes is driven by the detachment, via ion diffusion or 
complexation reaction, of metal centers from the reduced metal sites in the surface of the voltammetric peaks depend on the average particle size and the homogeneity of the particle size distribution [75,76]. Figure 5 compares the SWV response of four commercial pigments, Bohemian green, umber, Sienna raw and French ochre immersed into $0.10 \mathrm{M}$ $\mathrm{HCl}$. Although this electrolyte provides better discrimination between different iron oxide-based pigments than acetate buffer, the voltammograms of ochres from different provenances were quite similar, so that chemometric methods are needed for identification purposes [36].

The third important group of pigments is constituted by those displaying solid-state ion insertion (or de-insertion) processes, the typical case being the Prussian blue [23,24,7779], whereas much organic pigments experience solid state redox processes involving proton insertion/release [32-35,80,81]. This type of processes would be also involved in the electrochemistry of organic-inorganic hybrid materials [58-65,82].

Finally it is pertinent to note that: i) application of VIMP in the fields of archaeometry and conservation of heritage is complementary to the existing techniques; in general multi-technique approaches are needed for properly elucidating the composition of work of art samples; ii) the presented database can be viewed as a flexible tool for aiding to other more conventional in the identification of pigments; 'historical' pigments, however, can have a composition differing from their contemporary counterparts of the same nominal composition; iii) data analysis should take into account that pigment association to supports and bindings can distort the voltammetric response, as recently studied by the case of Egyptian blue in wall paintings [83].

\subsection{Application of ELCHER database to problem solving}

To illustrate the suitability of the ELCHER database for analyzing pictorial samples, it is shown the analyses of a blue-greenish sample from the canvas painting " $\mathrm{La}$ Degollación de los Inocentes" painted by the Valencian painter Miguel March $\left(17^{\text {th }}-18^{\text {th }}\right.$ century) (Fig. 6) and the analyses of a red sample from the canvas painting "Desposorios místicos de Santa Margarita" painted by the Italian painter Girolano Francesco Maria Mazzola (Il Parmigianino) (1503-1540) (Fig. 7). Cross-section 
obtained in the first sample shows a paint layer of blue-greenish color applied over a red earth ground. X-ray spectra obtained by means of spot analyses performed with FESEM-EDX in different grains (see Fig. 1S-4S in supplementary electronic material) enabled identification of a copper blue pigment (probably azurite), white lead and, present at lesser extent, lead-tin yellow.

Figure 8 depicts the voltammograms corresponding to the blue-greenish layer of sample S1 from the painting "La Degollación de los Inocentes". In the negative-going potential scan, a cathodic signal at $-0.10 \mathrm{~V}$ precedes a prominent signal at $-0.55 \mathrm{~V}$. Such signals are typical of copper and lead pigments, respectively, whose presence was confirmed by the appearance of stripping peaks at $-0.50 \mathrm{~V}$ (lead) and $+0.10 \mathrm{~V}(\mathrm{Cu})$. The shoulders at ca. $+0.40 \mathrm{~V}$ recorded in both voltammograms can be attributed to the presence of tin, suggesting the presence of the pigment lead-tin yellow. This was confirmed upon comparing the profile of the lead-centered signal with that of the pigment, shown in Figures 9a,b. The copper pigment in the blue-greenish paint layer was identified as azurite, as denoted upon comparison with the corresponding reference material, subsequently confirmed by means of the Tafel analysis of the voltammetric curves $[42,47]$. The detail of such voltammograms are depicted in Figures 9,c,d. It is of worth mention that X-ray microanalysis was unable to identify this mineral as this technique provides the elemental composition of the pigment.

In the red sample (S2) of the painting "Desposorios místicos de Santa Margarita", a mixture of lead white and vermilion, was identified by VIMP and FESEM-EDX (see Fig. 5S-7S in supplementary electronic material) [29]. This combination of pigments is frequently used by painters in flesh and in the lighted up parts of the draped red robes. The presence of lead white was denoted by the characteristic profile of the cathodic signal at ca. $-0.55 \mathrm{~V}$ (Figures 10a,b) whereas vermilion was detected by the anodic signal between 0.0 and $+0.2 \mathrm{~V}$ which can be seen in Figures $10 \mathrm{c}, \mathrm{d}$.

The application of the database to the study of metals and alloys and their corrosion products is illustrated in Figure 11, where the voltammograms of golden and silver bracelets from the Camí de la Bola archaeological site of the caliphal period (Xàtiva, Spain) are shown. Remarkably, this study was performed using a portable equipment 
(see Experimental section). To detect the presence of gold, $\mathrm{HCl}$ media was preferred due to the favorable oxidation to $\mathrm{AuCl}_{4}^{-}$[84]. On comparing the SWV of a sample from a golden bracelet (Fig. 11a) and a polycrystalline gold electrode (Fig. 11b); one can see that the gold-characteristic signal at ca. $+1.0 \mathrm{~V}$ is accompanied by signals at +0.45 , -0.10 and $-0.40 \mathrm{~V}$ representative of the stripping peaks of silver, copper and lead, respectively, denoting the complex composition of the sample. In the case of the negative-going scan voltammogram for a silver bracelet depicted in Figure 11c, now recorded in contact with acetate buffer, the reduction of $\mathrm{AgCl}$ at ca. $0.0 \mathrm{~V}$ is accompanied from that of silver tarnish $\left(\mathrm{Ag}_{2} \mathrm{~S}\right)$ at more negative potentials, thus denoting the presence of both alteration products. The first signal is overlapped with the reduction of any copper corrosion products ,as denoted by the positive-going scan voltammogram (Fig. 11d), where the stripping of copper at $+0.10 \mathrm{~V}$ is accompanied by two Ag stripping signals at +0.25 and $+0.45 \mathrm{~V}$, a feature previously observed in $\mathrm{Ag}$ coins [48].

\section{Conclusions}

The VIMP methodology can be used for identifying electroactive pigments and minerals in art and archaeological objects. Attachment of microsamples of commercial pigments and minerals to commercial graphite leads and aqueous electrolytes provide well-defined voltammetric responses under conditions accessible to conventional equipment. The ELCHER database, which includes voltammograms and ATR-FTIR, diffuse reflectance and X-ray spectral data, is presented as a tool for facilitating practical application of the VIMP in the domain of conservation and restoration of heritage as a technique that complement the non-electrochemical methodologies more extensively used in this field.

Acknowledgements: Research was conducted within the "Grupo de análisis científico de bienes culturales y patrimoniales y estudios de ciencia de la conservación" Microcluster of the University of Valencia Excellence Campus. Financial support is gratefully acknowledged from the MINECO Projects CTQ2014-53736-C3-1-P and -2-P which are also supported with ERDF funds. The authors would like to thank to Gonzalo Gironés Sarrió manager of GongDisseny Co. by the technical support for building the site structure and the structure of the database, Archbishop of Valencia, Dr. Ignacio 
Bosch Reig and Dr. Pilar Roig Picazo directors of the intervention project in the Basílica de la Virgen de los Desamparados de Valencia as well as Estrella Arcos Von Haartman and City Council Town of Málaga, as well as the Museum of Archaeology of Xàtiva, the curators Isabel Martínez Lázaro and Betlem Martínez and its director Angel Velasco for facilitating access to samples and Manuel Planes Insausti and Dr Jose Luis Moya López technical supervisors of the Electron Microscopy Service of the Universitat Politècnica de València where were carried out SEM-EDX analyses. 


\section{References}

[1] T. J. Reedy, Ch.L. Reedy, Statistical Analysis in Art Conservation Research, The Getty Conservation Institute, Los Angeles, 1988.

[2] F. Mairinger, M. Schreiner New methods of chemical analysis-a tool for the conservator, Science and Technology in the service of conservation, IIC, London, 1982, pp. 5-13.

[3] A. Wangm, J. Han, L. Guo, J. Yu, P. Zeng, Database of standard Raman spectra of minerals and related inorganic crystals, Appl. Spectrosc. 48 (1994) 959-968.

[4] I.M. Bell, R.J.H. Clark, P.J. Gibbs, Raman spectroscopic library of natural and synthetic pigments, Spectrochim. Acta 53A (1997) 2159-2179.

[5] Silva CE, Silva LP, Edwards HGM, de Oliveira LFC (2006) Diffuse reflection FTIR spectral database of dyes and pigments, Anal. Bioanal. Chem. 386: 2183-2191.

[6] P. Vandenabeele, B. Wehling, L. Moens, H.G.M. Edwards, M. de Reu M, G. Van Hooydonk, Analysis with micro-Raman spectroscopy of natural organic binding media and varnishes used in art, Anal. Chim. Acta 407 (2000) 261-274.

[7] P. Vandenabeele, L. Moens, H.G.M. Edwards, R. Dams, Raman spectroscopic database of azo pigments and application to modern art studies, J. Raman Spectrosc. 31 (2000) 509-517.

[8] L. Burgio, R.J.H. Clark, Library of FT-Raman spectra of pigments, minerals, pigment media and varnishes, Spectrochim. Acta A 57 (2001) 1491-1521.

[9] M. Bouchard, D.C. Smith, Catalogue of 45 reference Raman spectra of minerals concerning research in art history or archaeology, especially on corroded metals and coloured glass, Spectrochim. Acta A 59 (2003) 2247-2266.

[10] G. Burrafato, M. Calabrese, A. Cosentino, A.M. Gueli, S.O. Troja, A. Zuccarello, ColoRaman project: Raman and fluorescence spectroscopy of oil, tempera and fresco paint pigments, J. Raman Spectrosc. 35 (2004) 879-886.

[11] http/:www.irug.org ( $1^{\text {st }}$ February 2016).

[12] K. Castro, M. Pérez-Alonso, M.D. Rodríguez-Laso, L.A. Fernández, J.M. Madariaga, On-line FT-Raman and dispersive Raman spectra database of artist' materials (e-VISART database). Anal. Bioanal. Chem. 382 (2005) 248-258.

[13] K. Castro, M. Pérez, M.D. Rodríguez-Laso, J.M. Madariaga, FTIR spectra database of inorganic art materials, Anal. Chem. 75 (2003) 214A-221A.

[14] http/:www.ehu.es/udps/database/database.html ( $1^{\text {st }}$ February 2016). 
[15] http:// www.chem.ucl.ac.uk/resources/raman/speclib.html ( $1^{\text {st }}$ February 2016).

[16] http://minerals.gps.caltech.edu/ $\left(1^{\text {st }}\right.$ February 2016).

[17] http/:www.rruff.info ( $1^{\text {st }}$ February 2016).

[18] F. Scholz, L. Nitschke, G. Henrion, A New procedure for Fast Electrochemical Analysis of Solid Materials. Naturwiss. 76 (1989) 71-72.

[19] F. Scholz, L. Nitschke, G. Henrion, F. Damaschun, A New technique to Study the Electrochemistry of Minerals. Naturwiss. 76 (1989) 167-168.

[20] F. Scholz, L. Nitschke, G. Henrion, Identification of solid materials with a new electrochemical technique. Fresenius Z. Anal. Chem. 334 (1989) 56-58.

[21] F. Scholz, L. Nitschke, G. Henrion, F. Damaschun, Abrasive Stripping Voltammetry - the Electrochemical Spectroscopy for Solid State: Application for Mineral Analysis. Fresenius Z. Anal. Chem. 335 (1989) 189-194.

[22] B. Lange, F. Scholz, A. Weiss, G. Schwedt, J. Behnert, K.P. Raezke, Abrasive Stripping Voltammetry - the Electrochemical Alternative for Pigment Analysis- Internat. Lab. 23 (1993) 23-26.

[23] F. Scholz, B. Meyer, Voltammetry of solid microparticles immobilized on electrode surfaces. Electroanalytical Chemistry, A Series of Advances vol. 20 (1998) 1-86.

[24] F. Scholz, U. Schröder, R. Gulabowski, A. Doménech-Carbó, Electrochemistry of Immobilized Particles and Droplets, $2^{\text {nd }}$ edit. Monographs in Electrochemistry Series, F. Scholz, Ed. Springer, Berlin-Heidelberg (2014).

[25] A. Doménech-Carbó, J. Labuda, F. Scholz, Electroanalytical chemistry for the analysis of solids: characterization and classification (Technical Report). Pure Appl. Chem. 85 (2013) 609-631.

[26] A. Doménech-Carbó, M.T. Doménech-Carbó, V. Costa, Electrochemical Methods in Archaeometry, Conservation and Restoration. Monographs in Electrochemistry Series, F. Scholz, Ed. Springer, Berlin-Heidelberg (2009).

[27] A. Doménech-Carbó, Voltammetric methods applied to identification, speciation and quantification of analytes from works of art: an overview. J. Solid State Electrochem. 14 (2010) 363-379.

[28] A. Doménech-Carbó, Tracing, authentifying and dating archaeological metal using the voltammetry of microparticles. Anal. Methods 3 (2011) 2181-2188.

[29] A. Doménech-Carbó, M.T. Doménech-Carbó, M. Moyá-Moreno, J.V. GimenoAdelantado, F. Bosch-Reig, Identification of inorganic pigments from paintings and 
polychromed sculptures immobilized into polymer film electrodes by stripping differential pulse voltammetry. Anal. Chim. Acta, 407 (2000) 275-289.

[30] A. Doménech-Carbó, M.T. Doménech-Carbó, J.V. Gimeno-Adelantado, F. BoschReig, M.C. Saurí-Peris, S.Sánchez-Ramos, Electrochemistry of iron oxide pigments (earths) from pictorial microsamples attached to graphite/polyester composite electrodes. Analyst 126 (2001) 1764-1772.

[31] T. Grygar, P. Bezdicka, D. Hradil, A. Doménech-Carbó, F. Marken, L. Pikna, G. Cepria, Voltammetric analysis of iron pigments, Analyst 127 (2002) 1100-1107.

[32] T. Grygar, S. Kuckova, D. Hradil, D. Hradilova, Electrochemical analysis of natural solid organic dyes and pigments. J. Solid State Electrochem. 7 (2003) 706-713.

[33] A. Doménech-Carbó, M.T. Doménech-Carbó, M.C. Saurí-Peris, J.V. GimenoAdelantado, F. Bosch-Reig, Electrochemical identification of anthraquinone-based dyes in solid microsamples by square wave voltammetry using graphite/polyester composite electrodes. Anal. Bioanal. Chem. 375 (2003) 1169-1175.

[34] A. Doménech-Carbó, M.T. Doménech-Carbó, M.C. Saurí-Peris, Electrochemical identification of flavonoid dyes in work of art samples by abrasive voltammetry at paraffin-impregnated graphite electrodes. Talanta 66 (2005) 769-782.

[35] A. Doménech-Carbó, M.T. Doménech-Carbó, M.C. Saurí-Peris, J.V. GimenoAdelantado, F. Bosch-Reig, Identification of curcuma and safflower dyes by voltammetry of microparticles using paraffin-impregnated graphite electrodes. Microchim. Acta 152 (2005) 75-84.

[36] A. Doménech-Carbó, M.T. Doménech-Carbó, H.G.M. Edwards, Identification of Earth Pigments in Highly Damaged Frescoes by Applying Multivariate Chemometric methods to Solid State Voltammetry, Electroanalysis 19 (2007) 1890-1900.

[37] A. Doménech-Carbó, M.T. Doménech-Carbó, X. Mas-Barberá, Identification of lead pigments in nanosamples from ancient paintings and polychromed sculptures using voltammetry of nanoparticles/atomic force microscopy, Talanta 71 (2007) 1569-1579.

[38] A. Doménech-Carbó, M.T. Doménech-Carbó, H.G.M. Edwards, Application of Tafel analysis for quantitation in solid state voltammetry. Application to the analysis of cobalt and copper pigments in severely damaged frescoes, Anal Chem. 80 (2008) 2704-2716.

[39] V. Costa, K. Leyssens, A. Adriaens, N. Richard, F. Scholz, Electrochemistry reveals archaeological materials, J. Solid State Electrochem. 14 (2010) 449-451. 
[40] N. Souissi, L. Bousselmi, S. Khosrof, E. Triki, Electrochemical behavior of an archaeological bronze alloy in various aqueous media: New method for understanding artifacts preservation, Mater.Corr.54 (2003) 318-325.

[41] M. Serghini-Idrissi, M.C. Bernard, F.Z., Harrif, S. Joiret, K. Rahmouni, A. Srhiri, H. Takenouti, V. Vivier, M. Ziani, Electrochemical and spectroscopic characterizations of patinas formed on an archaeological bronze coin, Electrochim. Acta 50 (2005) 4699-4709.

[42] A. Doménech-Carbó, M.T. Doménech-Carbó, I. Martínez-Lázaro, Electrochemical identification of bronze corrosion products in archaeological artefacts. A case study. Microchim. Acta 162 (2008) 351-359.

[43] D. Satovic, S. Martinez, A. Bobrowski, Electrochemical identification of corrosion products on historical and archaeological bronzes using the voltammetry of microparticles attached to a carbon paste electrode, Talanta 81 (2010) 1760-1765.

[44] F.A. Gholenji, A. Adriaens, Electrochemical quantification of copper-based alloys using voltammetry of microparticles: optimization of the experimental conditions, J. Solid State Electrochem. 16 (2012) 535-543.

[45] D. Blum, W. Leyffer, R. Holze, Pencil-Leads as new electrodes for abrasive stripping voltammetry, Electroanalysis 8 (1996) 296-297.

[46] V. Costa, F. Urban, Lead and its alloys: metallurgy, deterioration and conservation, Reviews in Conservation, International Institute of Conservation 6 (2005) 48-62.

[47] A. Doménech-Carbó, M.T. Doménech-Carbó, M.A. Peiró-Ronda, One-touch' voltammetry of microparticles for the identification of corrosion products in archaeological lead. Electroanalysis 23 (2011) 1391-1400.

[48] A. Doménech-Carbó, M.T. Doménech-Carbó, T. Pasies, M.C. Bouzas-Bello, Application of modified Tafel analysis to the identification of corrosion products on archaeological metals using voltammetry of microparticles. Electroanalysis 23 (2011) 2803-2812.

[49] F. Rodríguez, J. Genescá, J. Uruchurtu, Electrochemical evaluation of patinas formed on nineteenth century bronze bells, J. Appl. Electrochem. 40 (2010) 311-320. [50] Y.V. Roblinetskaya, E.O. Il'inykch V.V. Slepushkin, A standardless method for the local electrochemical analysis of homogeneous alloys, J. Anal. Chem. 66 (2011) $84-87$. 
[51] A. Doménech-Carbó, M.T. Doménech-Carbó, I. Martínez-Lázaro, Layer-by-layer identification of copper alteration products in metallic works of art using the voltammetry of microparticles approach. Anal. Chim. Acta 610 (2010) 1-9.

[52] A. Doménech-Carbó, M.T. Doménech-Carbó, M.A. Peiró-Ronda, L. OseteCortina, Authentication of archaeological lead artifacts using voltammetry of microparticles: the case of the Tossal de Sant Miquel Iberian plate. Archaeometry 53 (2011) 1193-1211.

[53] A. Doménech-Carbó, M.T. Doménech-Carbó, M. Lastras, M. Herrero, 2015. Detection of archaeological forgeries of Iberian lead plates using nanoelectrochemical techniques. The lot of fake plates from Bugarra (Spain). Forensic Sci. Int. 247 (2015) 79-88.

[54] A. Doménech-Carbó, M.T. Doménech-Carbó, M.A. Peiró-Ronda, Dating archaeological lead artifacts from measurement of the corrosion content using the voltammetry of microparticles, Anal. Chem. 83 (2011) 5639-5644.

[55] A. Doménech-Carbó, M.T. Doménech-Carbó, M.A. Peiró-Ronda, I. MartínezLázaro, Application of the voltammetry of microparticles for dating archaeological lead using polarization curves and electrochemical impedance spectroscopy. J. Barrio. J. Solid State Electrochem. 16 (2012) 2349-2356.

[56] A. Doménech-Carbó, M.T. Doménech-Carbó, S. Capelo, T. Pasíes, I. MartínezLázaro, Dating archaeological copper/bronze artifacts using the voltammetry of microparticles. Angew. Chem. Int. Ed. 53 (2014) 9262-9266.

[57] A. Doménech-Carbó, S. Capelo, J. Piquero-Cilla, M.T. Doménech-Carbó, L. Barrio, A. Fuentes, W. Al-Sekkaneh, Dating archaeological copper using electrochemical impedance spectroscopy. Comparison with voltammetry of microparticles dating. Mater. Corr. 67 (2016) 120-129.

[58] A. Doménech-Carbó, M.T. Doménech-Carbó, M.L. Vázquez de Agredos, Dehydroindigo: a New Piece into the Maya Blue Puzzle from the Voltammetry of Microparticles Approach. J. Phys. Chem. B 110 (2006) 6027-6039.

[59] A. Doménech-Carbó, M.T. Doménech-Carbó, M.L. Vázquez de Agredos, Chemometric Study of Maya Blue from the Voltammetry of Microparticles Approach. Anal. Chem. 79 (2007) 2812-2821.

[60] A. Doménech-Carbó, M.T. Doménech-Carbó, M. Sánchez del Río, M.L. Vázquez de Agredos, E. Lima, Maya Blue as a nanostructured polyfunctional hybrid organic-inorganic 
material: the need to change paradigms, New J. Chem. 33 (2009) 2371-2379.

[61] A. Doménech-Carbó, M.T. Doménech-Carbó, M.L. Vázquez de Agredos, From Maya Blue to 'Maya Yellow': A Connection between Ancient Nanostructured Materials from the Voltammetry of Microparticles. Angew. Chem. Int. Ed. 50 (2011) 5741-5744. [62] A. Doménech-Carbó, M.T. Doménech-Carbó, C. Vidal-Lorenzo, M.L. Vázquez de Agredos, Insights into the Maya Blue Technology: Greenish Pellets from the Ancient City of La Blanca. Angew. Chem. Int. Ed. 51 (2012) 700-703.

[63] A. Doménech-Carbó, M.T. Doménech-Carbó, C. Vidal-Lorenzo, M.L. Vázquez de Agredos, L. Osete-Cortina, F.M. Valle-Algarra, Discovery of indigoid-containing clay pellets from La Blanca: significance with regard to the preparation and use of Maya Blue. J. Archaeol. Sci. 41 (2014) 147-155.

[64] A. Doménech-Carbó, M.T. Doménech-Carbó, F.M. Valle-Algarra, M.E. Domine, L. Osete-Cortina, On the dehydroindigo contribution to Maya Blue. J. Mater. Sci. 48 (2013) 7171-7183.

[65] G. Sciutto, S. Prati, R. Mazzeo, M. Zangheri, A. Roda, L. Bardini, G. Valenti, S. Rapino, M. Marcaccio, Localization of proteins in paint cross-sections by scanning electrochemical microscopy as an alternative immunochemical detection technique. Anal. Chim. Acta 831 (2014) 31-37.

[66] A. Doménech-Carbó, M.T. Doménech-Carbó, M. Silva, F.M. Valle-Algarra, J.V. Gimeno-Adelantado, F. Bosch-Reig, R. Mateo-Castro, Screening and mapping pigments in paintings using scanning electrochemical microscopy (SECM). Analyst 140 (2015) 1065-1075.

[67] H.S. Wang, H.X. Ju, H.Y. Chen, Simultaneous determination of guanine and adenine in DNA using an electrochemically pretreated glassy carbon electrode. Anal. Chim. Acta 461 (2002) 243-250.

[68] Y. Tao, Z.J. Lin, X.M. Chen, X.I. Chen, X.R. Wang, Tris(2,2'bipyridyl)ruthenium(II) electrochemiluminescence sensor based on carbon nanotube/organically modified silicate films. Anal. Chim. Acta 594 (2007) 169-174.

[69] U. Hasse, F. Scholz, In situ Atomic Force Microscopy of the Reduction of Lead Oxide Nanocrystals Immobilized on an Electrode Surface, Electrochem. Commun. 3 (2001) 429-434. 
[70] U. Hasse, J. Nieven, F. Scholz, Atomic force Microscopy of the Electrochemical Reductive Dissolution of Sub-Micrometer Sized Crystals of Goethite Immobilized on a Gold Electrode. J. Electroanal. Chem. 556 (2003) 13-22.

[71] U. Hasse, K. Wagner, F. Scholz, Microscopy of the Electrochemical Reduction of Sub Micrometer Size Silver and Mercury(I) Halide Crystals Immobilized on Gold Electrodes. J. Solid State Electrochem. 8 (2004) 842-853.

[72] V. Mirceski, S. Komorsky-Lovirc, M. Lovric, Square Wave Voltammetry -Theory and Applications- Monographs in Electrochemistry Series, F. Scholz, Ed. Springer, Berlin-Heidelberg, 2002.

[73] S. Komorsky-Lovric, M. Lovric, A.M. Bond, Comparison of the square-wave stripping voltammetry of lead and mercury following their electrochemical or abrasive deposition onto a paraffin impregnated graphite electrode. Anal. Chim. Acta 258 (1992) 299-305.

[74] Zakharchuk, S. Meyer, B. Lange, F. Scholz, A Comparative Study of Lead Oxide Modified Graphite Paste Electrodes and Solid Graphite Electrodes with Mechanically Immobilized Lead Oxides, Croat. Chem. Acta 73 (2000) 667-704.

[75] T. Grygar, Kinetics of Electrochemical Reductive Dissolution of Iron(III) HydoxyOxides. Coll Czech Chem Commun 60 (1995) 1261-1273.

[76] T. Grygar, Dissolution of pure and substituted goethites controlled by the surface reaction under conditions of abrasive stripping voltammetry. J. Solid State Electrochem. 1 (1997) 77-82.

[77] F. Scholz, A. Dostal, The Formal Potentials of the Solid Metal Hexacyanometalates, Angew. Chem. 107 (1995) 2876-2878 (Angew. Chem. Int. Ed. Engl. 34 (1996) 2685-2687).

[78] A. Dostal, B. Meyer, F. Scholz, U. Schröder, A.M. Bond, F. Marken, Sh.J. Shaw, Electrochemical Study of Microcrystalline Solid Prussian Blue Particles Mechanically Attached to Graphite and Gold Electrodes: Electrochemically Induced Lattice Reconstruction. J Phys. Chem. 99 (1995) 2096-2103.

[79] Kahlert, U. Retter, H. Lohse, K. Siegler, F. Scholz, On the Determination of the Diffusion Coefficients of Electrons and Potassium Ions in Copper(II) Hexacyanoferrate(II). J. Phys. Chem. B 102 (1998) 8757-8765.

[80] A. Doménech-Carbó, M.T. Doménech-Carbó, Chronoamperometric study of proton transfer/electron transfer in solid state electrochemistry of organic dyes. J. Solid State 
Electrochem. 10 (2006) 949-958.

[81] A. Doménech-Carbó, M.T. Doménech-Carbó, In situ AFM study of proton-assisted electrochemical oxidation/reduction of microparticules of organic dyes. Electrochem. Commun. 10 (2008) 1238-1241.

[82] A. Doménech-Carbó, Theoretical scenarios for the electrochemistry of porous silicate-based materials: an overview. J. Solid State Electrochem. 19 (2015) 1887-1903.

[83] A. Doménech-Carbó, M.T. Doménech-Carbó, F. López, F.M. Valle-Algarra, L. Osete-Cortina, E. Arcos, Electrochemical characterization of Egyptian blue pigment in wall paintings using the voltammetry of microparticles methodology. Electroanalysis 25 (2013) 2621-2630.

[84] A. Doménech-Carbó, M.T. Doménech-Carbó, L. Osete-Cortina, Electrochemistry of archaeological metals: an approach from the voltammetry of microparticles, en "Trends in electrochemistry and corrosion at the beginning of the 21st century (dedicated to Professor Dr. Josep M. Costa on the occasion of his $70^{\text {th }}$ birthday); Brillas, E. Cabot, P.-L. Edits. Universitat de Barcelona, Barcelona (2004). 


\section{Figures}

Figure 1. a) Main menu of the web site ELCHER; b) Main menu of the ELCHER database with the description of the ELCHER voltammogram database initiative, terms of use and legal conditions.

Figure 2. a) Main menu of the ELCHER database; b) Record card of azurite pigment with the voltammogram, IR spectrum, UV-vis spectrum, backscattered electron image and $\mathrm{x}$-ray spectrum as seen on the online ELCHER database.

Figure 3. CV of a malachite (K10300) deposit on graphite bar (Staedtler) immersed into $0.25 \mathrm{M} \mathrm{HAc} / \mathrm{NaAc}, \mathrm{pH} 4.75$. Potential scan initiated at $+0.75 \mathrm{~V}$ in the negative direction. Potential step increment $4 \mathrm{mV}$; square wave amplitude $25 \mathrm{mV}$; frequency 5 $\mathrm{Hz}$.

Figure 4. SWV of malachite (K10300) deposits on a) Alpino, b) Staedtler, c) Disnak and d) Hoc-i-Noor graphite bars immersed into 0.25 M HAc/NaAc, pH 4.75. Potential scan initiated at $+0.85 \mathrm{~V}$ in the negative direction. Potential step increment $4 \mathrm{mV}$; square wave amplitude $25 \mathrm{mV}$; frequency $5 \mathrm{~Hz}$.

Figure 5. SWV of: Bohemian green (K17800); b) Umber (K40610); c) Sienna (K40451); d) French ochre (K40090) on Alpino lead in contact with $0.10 \mathrm{M} \mathrm{HCl}$. Potential scan initiated at $+0.85 \mathrm{~V}$ in the negative direction. Potential step increment 4 $\mathrm{mV}$; square wave amplitude $25 \mathrm{mV}$; frequency $5 \mathrm{~Hz}$.

Figure 6. a) "La degollación de los Inocentes" painted by the Valencian painter Miguel March (17th-18th century, belongs to the Basílica de la Virgen de los Desamparados canvas collection (Valencia, Spain)). b) Cross-section of the sample blue-greenish taken in the point marked with a spot: (1) paint layer, (2) ground.

Figure 7. a) "Desposorios místicos de Santa Margarita" painted by the Italian painter Girolano Francesco Maria Mazzola (Il Parmigianino) (1503-1540) exhibited in the Hall town of Malaga, b) Cross-section of the sample red R: (1) paint layer, (2) ground. 
Figure 8. SWVs of sample S1 from "La degollación de los Inocentes" on graphite lead (Staedtler) in contact with $0.25 \mathrm{M} \mathrm{HAc/NaAc}, \mathrm{pH} 4.75$. Potential scan initiated at a) $+1.05 \mathrm{~V}$ in the negative direction; b) $-1.05 \mathrm{~V}$ in the positive direction. Potential step increment $4 \mathrm{mV}$; square wave amplitude $25 \mathrm{mV}$; frequency $5 \mathrm{~Hz}$. (Tly: tin lead yellow; Az: azurite).

Figure 9. Detail of two potential regions in the SWVs on graphite lead (Staedtler) in contact with $0.25 \mathrm{M} \mathrm{HAc/NaAc}, \mathrm{pH} 4.75$ for: a) sample $\mathrm{S} 1$; b) lead-tin yellow; a) sample S1; b) azurite. Potential scan initiated at $+1.05 \mathrm{~V}$ in the negative direction. Potential step increment $4 \mathrm{mV}$; square wave amplitude $25 \mathrm{mV}$; frequency $5 \mathrm{~Hz}$.

Figure 10. Detail of the SWVs on sample S2 from "Desposorios místicos de Santa Margarita" attached to graphite lead (Staedtler) in contact with $0.25 \mathrm{M} \mathrm{HAc/NaAc}, \mathrm{pH}$ 4.75 for: a) sample S2; b) lead white; c) sample S2; d) vermilion. Potential scan initiated at $-1.05 \mathrm{~V}$ in the positive direction. Potential step increment $4 \mathrm{mV}$; square wave amplitude $25 \mathrm{mV}$; frequency $5 \mathrm{~Hz}$.

Figure 11. SWVs of: a) sample from a golden sculpture; b) gold electrode; c,d) silver bracelet from the Camí de la Bola archaeological site recorded using a portable equipment. a,c,d) samples taken using the 'one-touch' procedure at Staedtler graphite bars. Electrolytes, aqueous a,b) $0.10 \mathrm{M} \mathrm{HCl}$; c,d) $0.25 \mathrm{M} \mathrm{HAc/NaAc,} \mathrm{pH} \mathrm{4.75,}$ solutions. a, b, d) Positive-going scans; c) negative-going scan. Potential step increment $4 \mathrm{mV}$; square wave amplitude $25 \mathrm{mV}$; frequency $5 \mathrm{~Hz}$. 
Figure 1.

1

2

3

4

5

9

10

11

12

13

14

15

16

17

18

19

20

21

22

23

24

25

26

27

28

29

30

31

32

33

34

35

36

37

38

39

40

41

42

43

44

45

46

47

48

49

50

51

52

53

54

55

56

57

58

59

60

61

62 a)

\section{ElcHer}

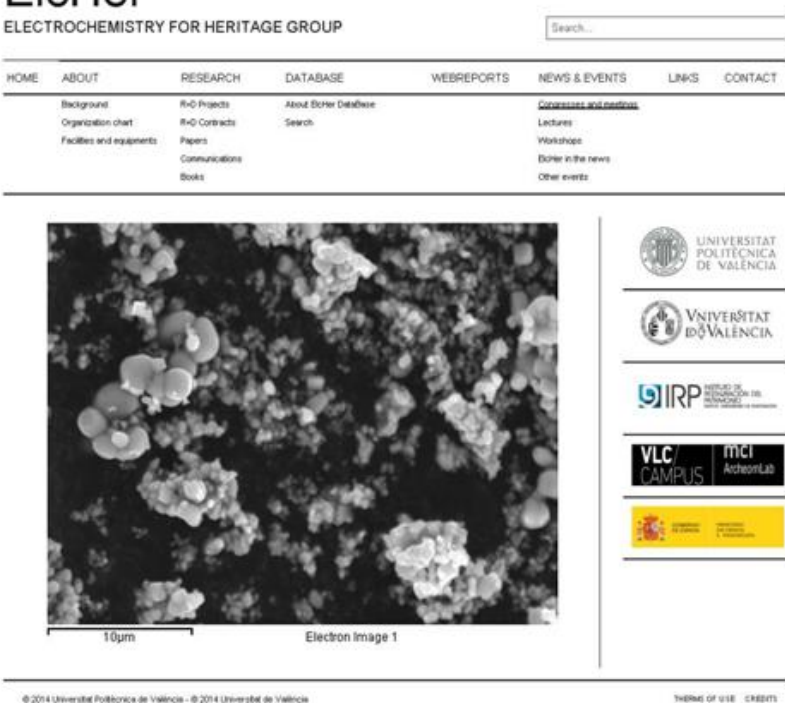

b)

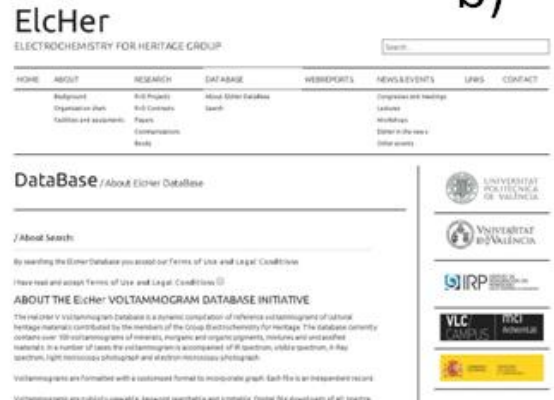

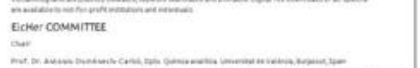
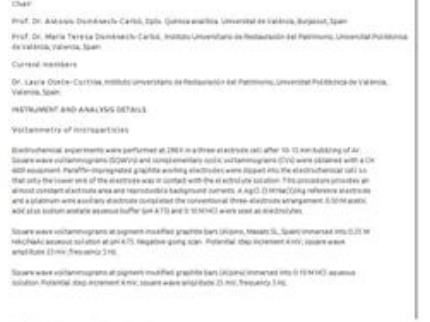


\section{Figure 2}

1

2 a)

\section{ElcHer}

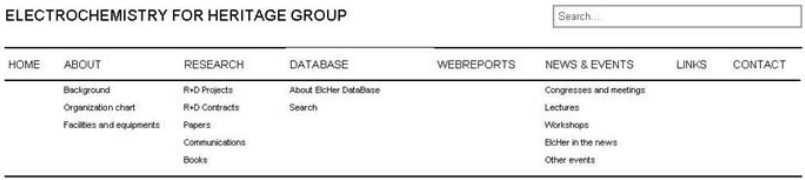

DataBase / search

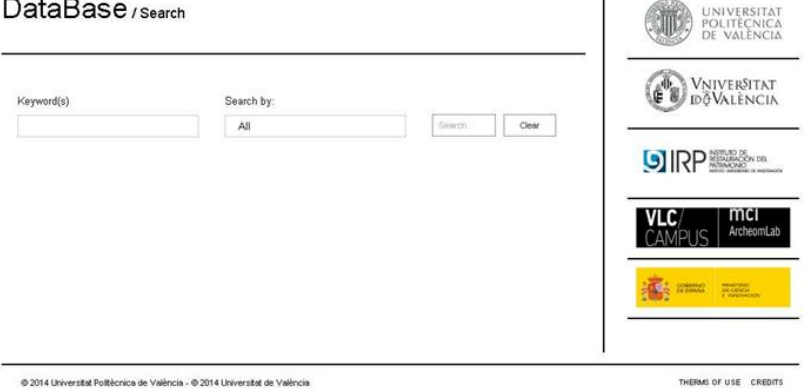

b)

\section{ElcHer}

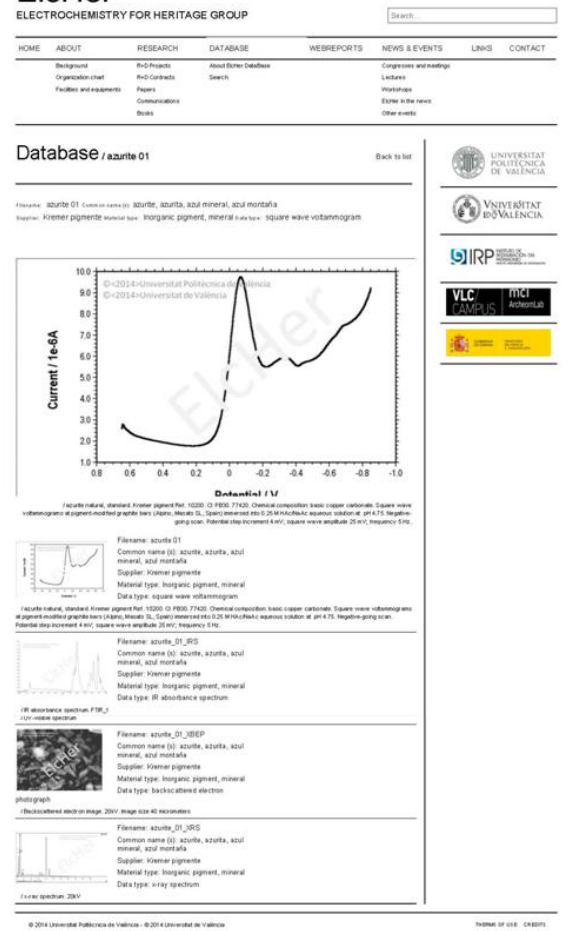


Figure 3

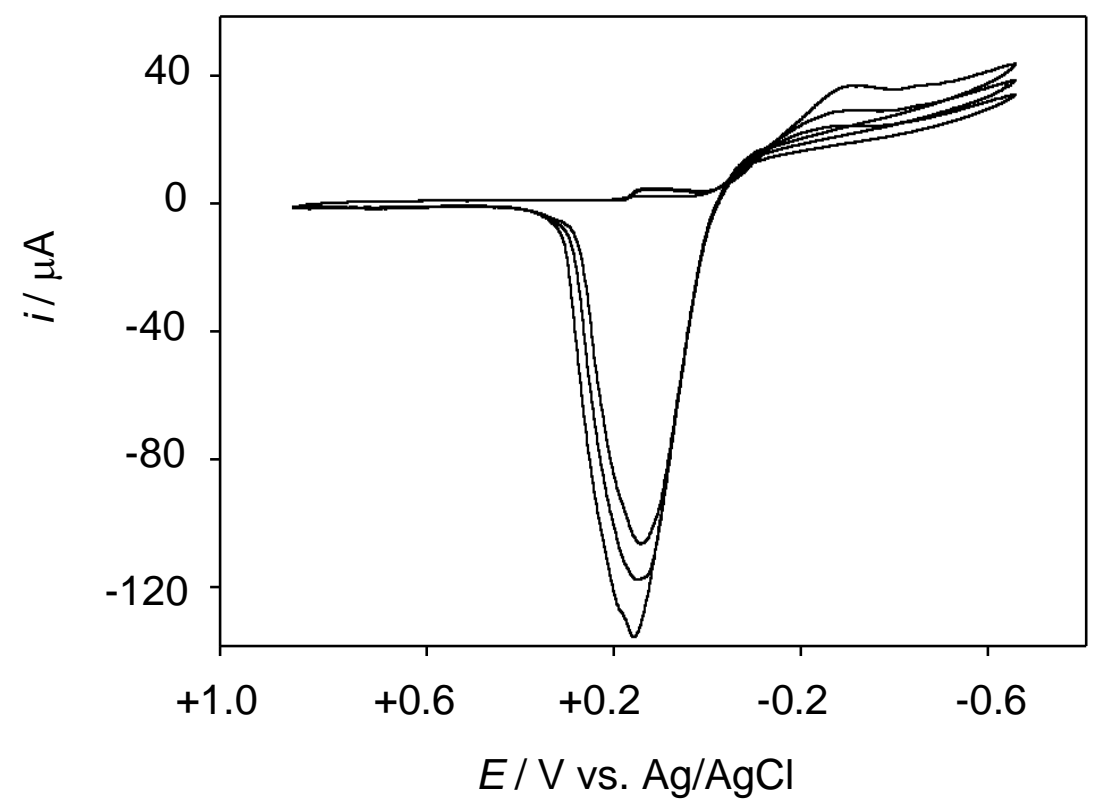


Figure 4.

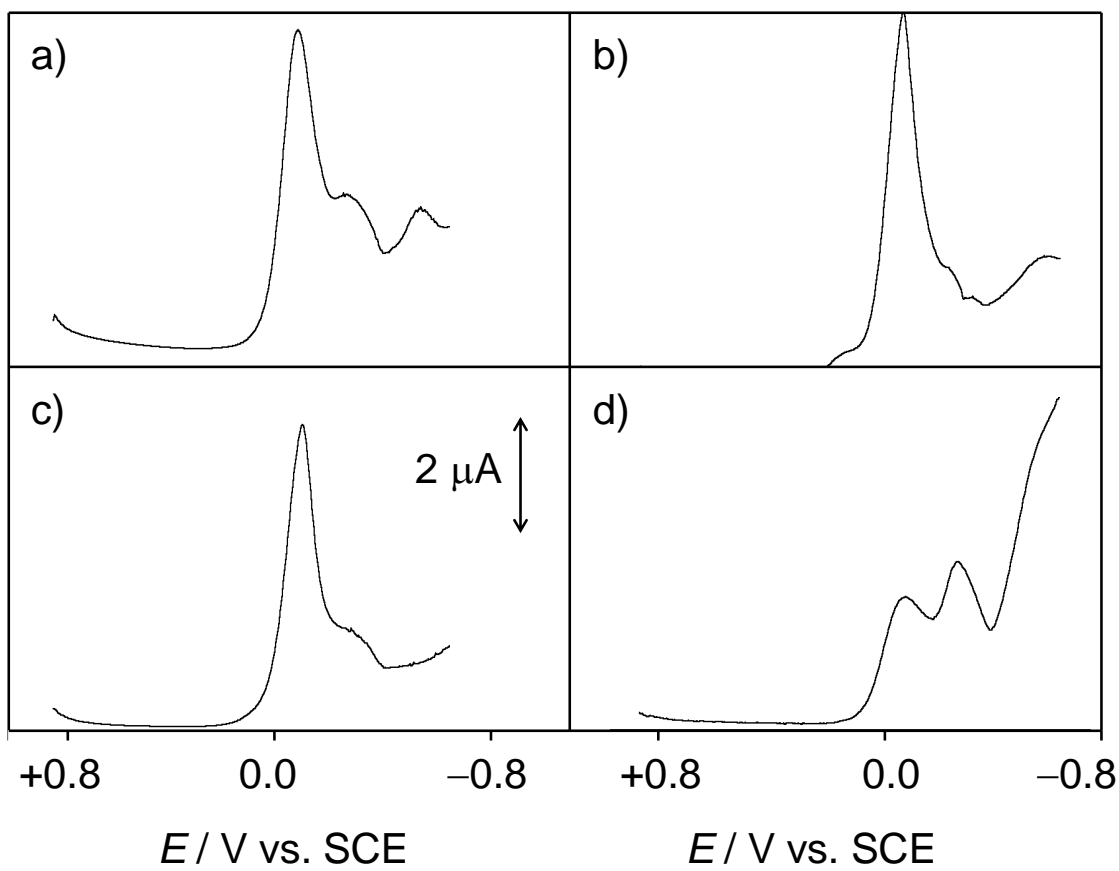


Figure 5.

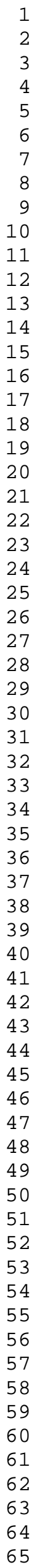

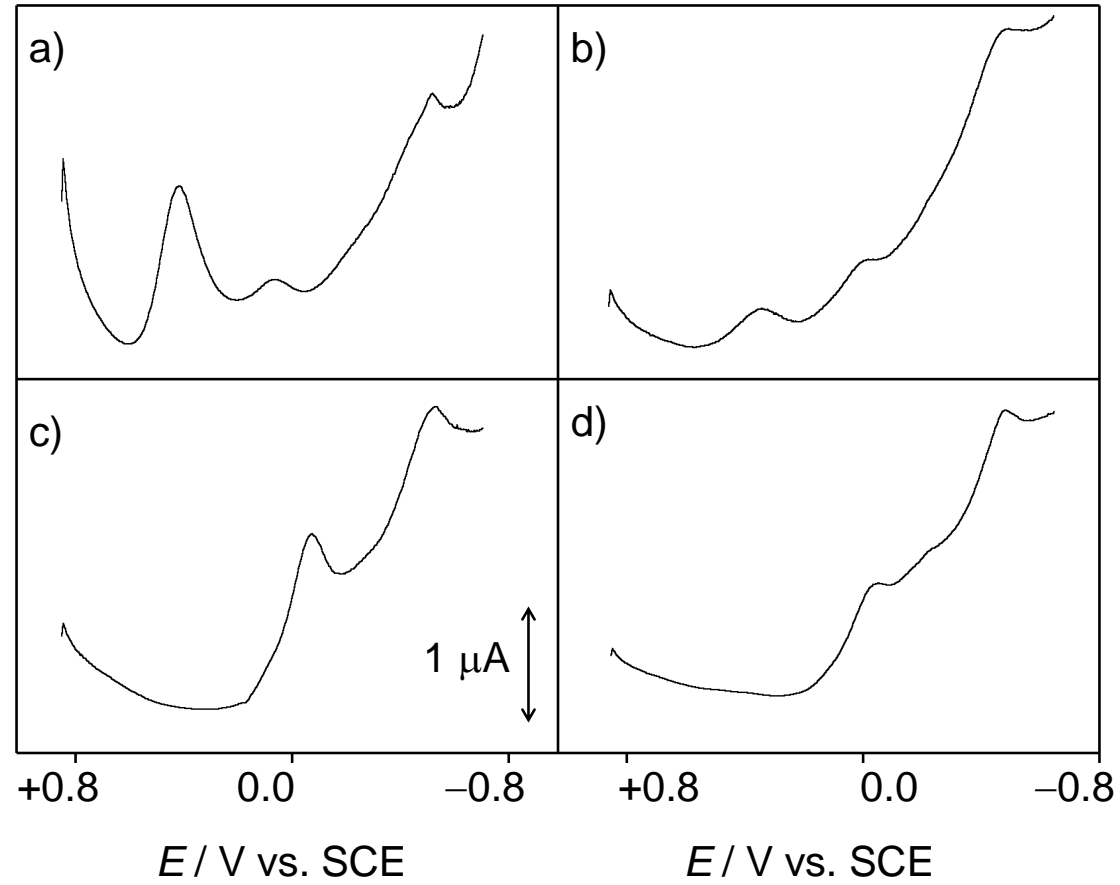


Figure 6.

1

2

3

4

5

6

9

10

11

12

13

14

15

16

17

18

19

20

21

22

23

24

25

26

27

28

29

30

31

32

33

34

35

36

37

38

39

40

41

42

43

44

45

46

47

48

49

50

51

52

53

54

55

56

57

58

59

60

61

62

63

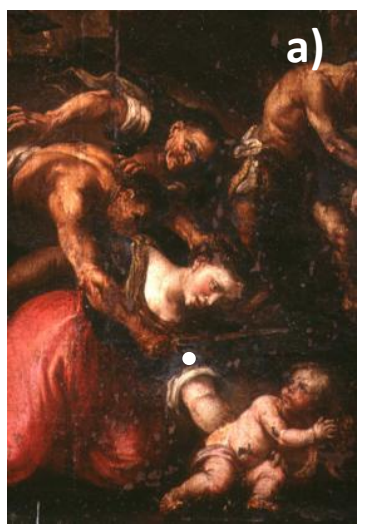

$200 \mu \mathrm{m}$

b)

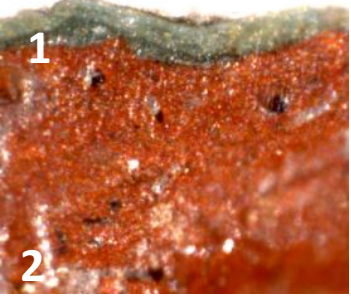

65 
Figure 7

1

2

3

4

5

6

7

8

9

10

11

12

13

14

15

16

17

18

19

20

21

22

23

24

25

26

27

28

29

30

31

32

33

34

35

36

37

38

39

40

41

42

43

44

45

46

47

48

49

50

51

52

53

54

55

56

57

58

59

60

61

62

63

64

65

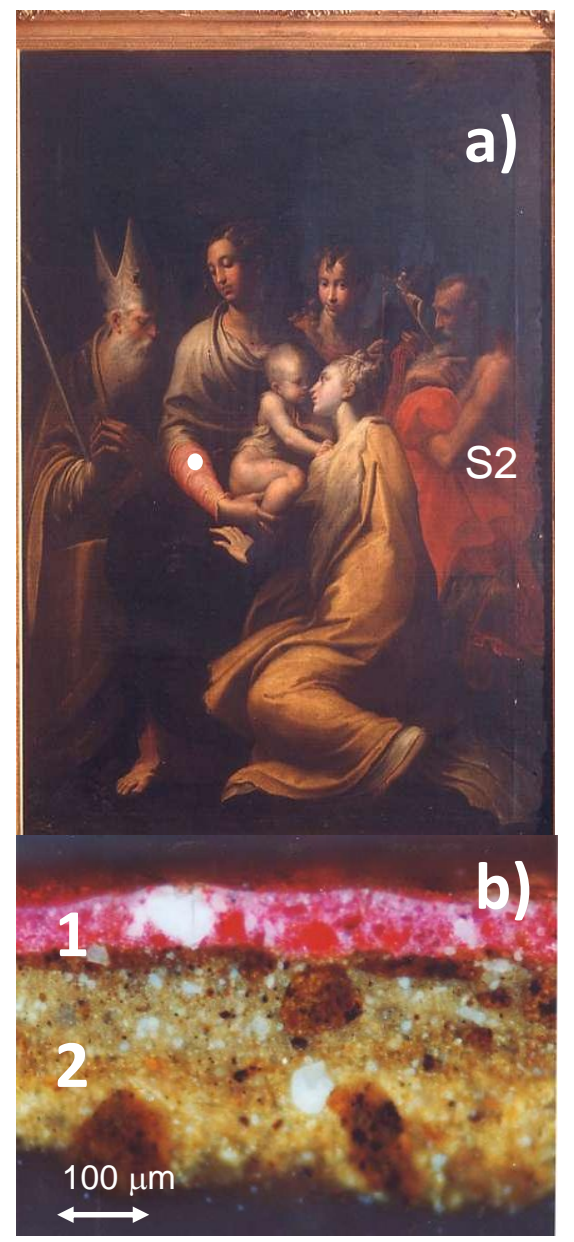


Figure 8.

1

2

3

4

5

6

7

8

9
10

11

12

13

14

15

16

17

18

19

20

21

22

23

24

25

26

27

28

29

30

31

32

33

34

35

36

37

38

39

40

41

42

43

44

45

46

47

48

49

50

51

52

53

54

55

56

57

58

59

60

61

62

63

64

65

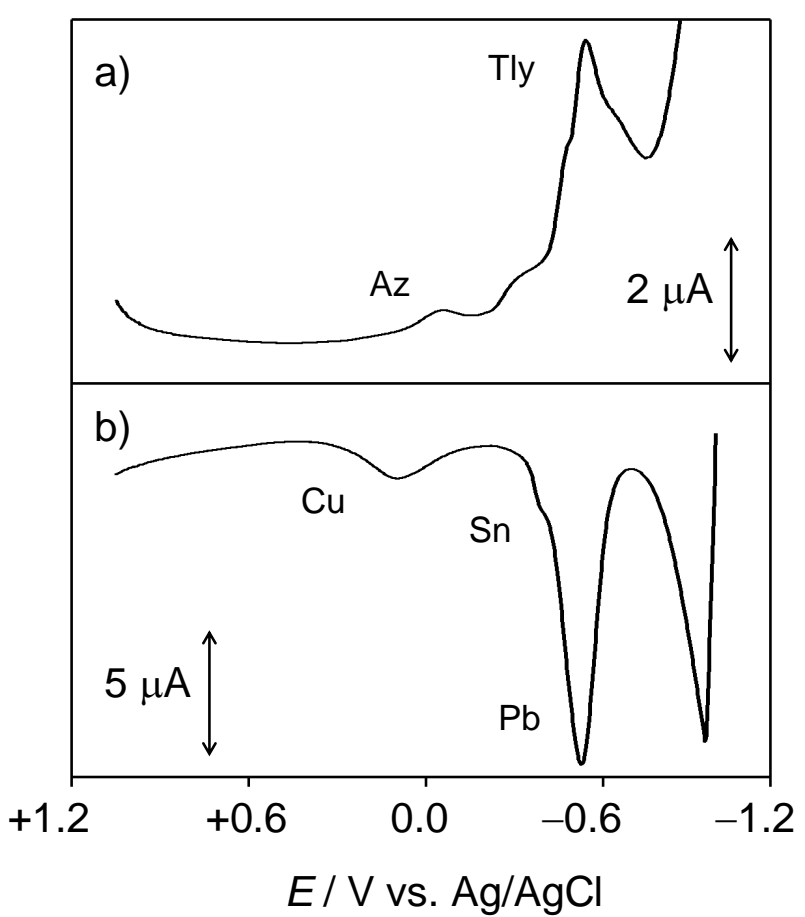


Figure 9.

1

2

3

4

5

6

7

8

10

11

12

13

14

15

16

17

18

19

20

21

22

23

24

25

26

27

28

29

30

31

32

33

34

35

36

37

38

39

40

41

42

43

44

45

46

47

48

49

50

51

52

53

54

55

56

57

58

59

60

61

62

63

64

65

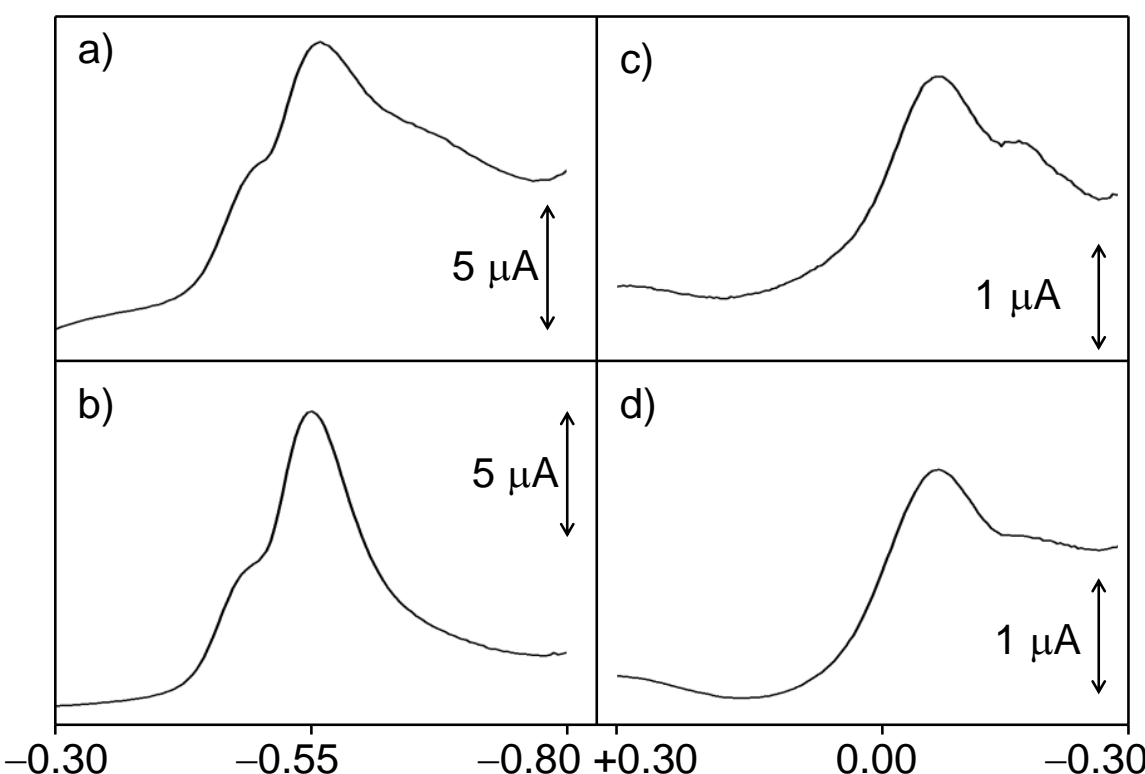

$E / \mathrm{Vvs} . \mathrm{Ag} \mid \mathrm{AgCl} \quad E / \mathrm{V}$ vs. $\mathrm{Ag} \mid \mathrm{AgCl}$ 
Figure 10.

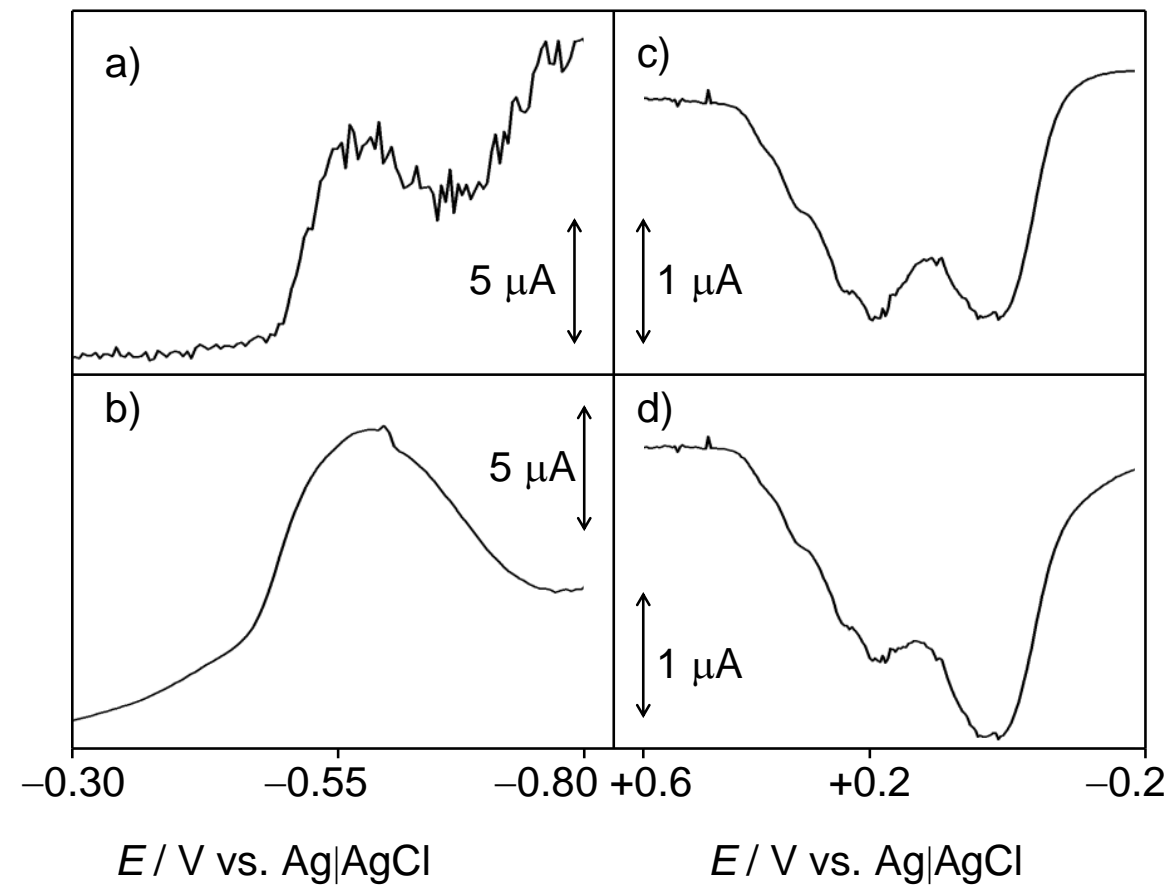

31

32

33

34

35

36

37

38

39

40

41

42

43

44

45

46

47

48

49

50

51

52

53

54

55

56

57

58

59

60

61

62 
Figure 11.

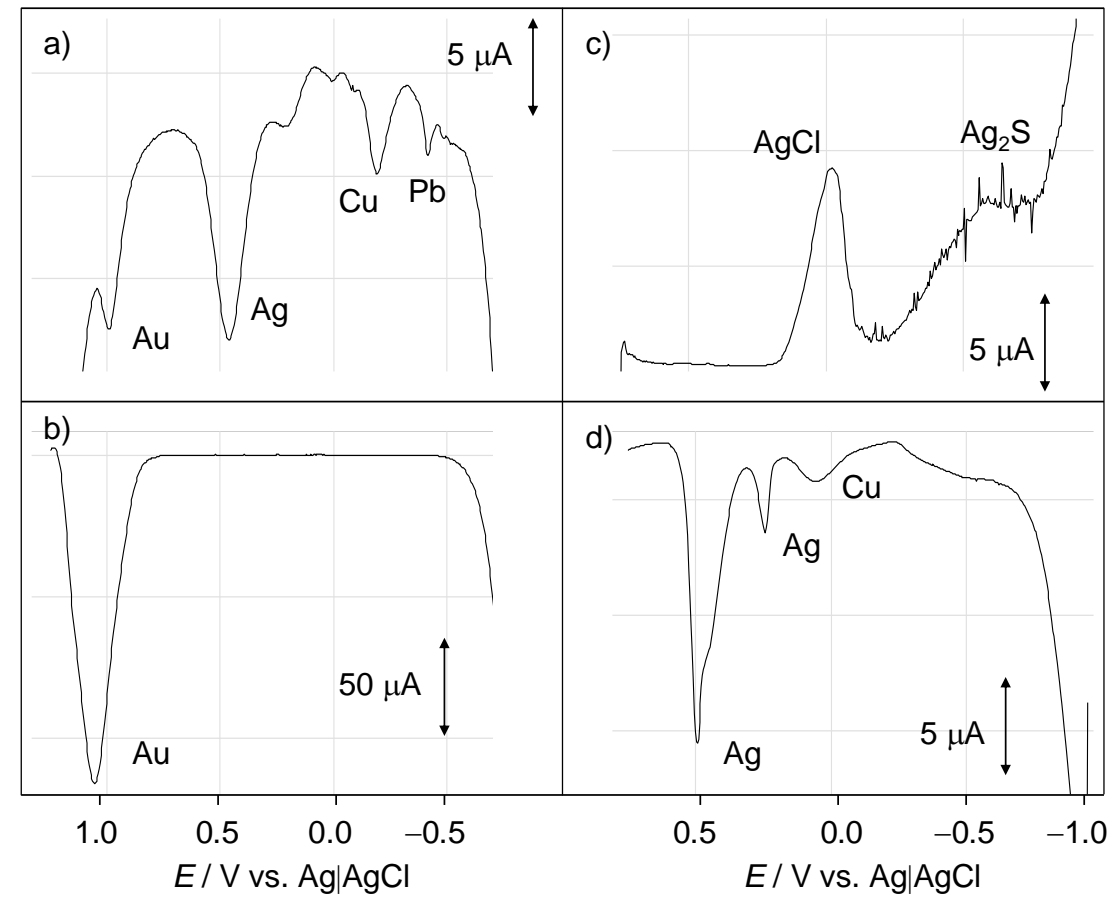

31

32

33

34

35

36

37

38

39

40

41

42

43

44

45

46

47

48

49

50

51

52

53

54

55

56

57

58

59

60

61

62 
Electronic Supplementary Material (online publication only)
Click here to download Electronic Supplementary Material (c

Electronic Supplementary Material (online publication only)
Click here to download Electronic Supplementary Material (online publication only): ELCHERSupplementaryelectronic material. 